\title{
Zinc-gene interaction related to inflammatory/immune response in ageing
}

\author{
Eugenio Mocchegiani $\cdot$ Marco Malavolta
}

Published online: 20 June 2008

(C) Springer-Verlag 2008

\begin{abstract}
The pivotal role played by zinc-gene interaction in affecting some relevant cytokines (IL-6 and TNF- $\alpha$ ) and heat shock proteins (HSP70-2) in ageing, successful ageing (nonagenarians) and the most common age-related diseases, such as atherosclerosis and infections, is now recognized. The polymorphisms of genes codifying proteins related to the inflammation are predictive on one hand in longevity, on the other hand they are associated with atherosclerosis or severe infections. Since the health lifespan has a strong genetic component, which in turn also affected by nutritional factors like zinc, the association of these polymorphisms with innate immune response, zinc ion bioavailability and Metallothioneins (MT) homeostasis is an useful tool to unravel the role played by zinc-gene interactions in longevity, especially due to the inability of MT in zinc release in ageing and chronic inflammation. In ageing, this last fact leads to depressed innate immune response for host defence. In contrast, in very old age the inflammation is lower with subsequent more zinc ion bioavailability, less MT gene expression and satisfactory innate immunity. Therefore, the zinc-gene (IL-6, TNF- $\alpha$, Hsp70-2) interactions, via MT homeostasis, are crucial to achieve successful ageing.
\end{abstract}

Keywords Polymorphism - Zinc $\cdot$ Metallothionein · Cytokine $\cdot$ Heat Shock protein - Inflammation · Immune response · Longevity

E. Mocchegiani $(\bowtie) \cdot$ M. Malavolta Immunology Center (Laboratory of Nutrigenomic and Immunosenescence), Research Department, INRCA, Via Birarelli 8, 60121 Ancona, Italy

e-mail: e.mocchegiani@inrca.it

\section{Human genes and longevity}

Ageing is a universal phenomenon that affects nearly all of animal species. According to Helfand and Rogina [69], ageing can be characterized as: (1) an inevitable consequence of being a multicellular organism; (2) associated with a random, passive decline in function; (3) leading to a global loss of homeostasis over time and (4) mortality increasing with ageing. Evolutionary studies on ageing have drawn the attention on the importance of the genetic mechanisms involved in somatic maintenance and repair that secure longevity [82]. Evidence from model organisms has indicated that subtle variation in the genes can dramatically influence lifespan. However, findings on potential candidate genetic mechanisms determining ageing and lifespan in model organisms are far to explain variations in human populations because phenotypes are critically dependent on the setting in which genes are expressed, while laboratory conditions and modern environments are markedly dissimilar [86]. Genetic analysis of human ageing is mainly approached by searching the genetic basis of susceptibility to major geriatric disorders or the allelic contributions to exceptionally long life span. It is just thanks to these last studies in centenarians populations that several candidate longevity genes or pathways including PON1 [19, 130], IGF1/insulin pathway [84, 120], elements of lipid metabolism [12], stress response [34] and inflammatory response have been identified [53].

Genes related to inflammation and stress response, in particular the pro-inflammatory cytokines IL-1, IL-6, TNFalpha, the anti-inflammatory cytokine IL-10, the HSP70 chaperones and the regulators of trace elements homeostasis, metallothioneins (MT), seem particularly relevant taking into account that the same genes are involved in the susceptibility to major geriatric disease/disorders such as 
diabetes, osteoporosis, osteoarthritis, dementia, cardiovascular diseases and infections [53, 107]. Moreover, in the context of human longevity these genes acquire particular weight because, conversely to typical lab organisms usually housed in pathogen-free environments and thus underexposed to pathogens, the humans live in a controlled but not sterile environment [54] responsible for a lifelong antigenic load.

Two complementary arms of the immune system protect humans from pathogens: natural (innate) immunity and adaptive (acquired) immunity. Innate immunity is our first line of defence called to act immediately after the body encounters a pathogen and it is supported by neutrophils, dendritic cells, macrophages, natural killer (NK) cells and the complement system.

Adaptive immunity responds slower to pathogens but more specifically and can "memorize" an intruder and acts more rapidly to fight it when a second encounter arises. It is supported by $\mathrm{T}$ lymphocytes, which contribute to cellular immunity and B lymphocytes, which produce specific antibodies against pathogens (humoral immunity).

Immune response, inflammation and stress response are part of an integrated and evolutionary highly conserved set of response crucial for survival and aimed to counteract all kind of stressors impacting on the body and potentially dangerous for survival [54]. Inflammation is necessary to cope with damaging agents and is crucial for survival, particularly during our reproductive years. However, as a result of the lifelong antigenic load a chronic, low grade inflammatory status associated with an exhaustion of the adaptive/clonotypical immunity, progressively emerges as a characteristic of ageing [52]. Indeed, the term "inflammaging" has been coined to describe these underlying inflammatory changes associated with ageing [52]. In this period of life largely unforeseen by evolution, the role of pro-inflammatory cytokines devoted to the neutralization of harmful agents early in life may become detrimental as macrophages and neutrophils are excessively stimulated to release cytotoxic compounds [54]. This phenomenon is largely attributed to the evolutionary pressure on our immune system which, in turn, evolved to be quite efficient in coping with acute infections in young age, but not with chronic/sub-chronic bacterial and viral infections lasting for decades in old age [54]. Thus, excessive production of pro-inflammatory cytokines, HSPs and alterations of innate and adaptive immune response can lead to an "extra", not strictly "necessary", immunological burden that may determine the onset of age-related pathologies bearing a strong inflammatory pathogenetic component. Within this perspective, healthy ageing and longevity, which appears to have a remarkable and strong genetic component [51], are likely the result of a lower propensity to mount inflammatory responses without compromising an acute response when exposed to pathogens [54]. As a result, in order to become centenarian, it is necessary to successfully cope with the common diseases at young age as well to escape or to delay the major age-associated diseases. Another important factor in longevity is the anti-inflammatory component. In fact, a low grade chronic inflammation is present also in those exceptional individuals who escaped the major age-related diseases [54]. This apparent dichotomy can be explained considering that the age-related increase of inflammatory markers in long living individuals is generally counterbalanced by an antiinflammatory response through the production of antiinflammatory agents (i.e. cortisol, TGF-beta, IL-10, lipoxins) [54]. Therefore, the key of successful ageing and longevity is likely the result not only of a reduced proinflammatory capacity but also of an efficient anti-inflammatory networks, which in normal ageing fails to fully neutralize the inflammatory processes consequent to the lifelong antigenic burden and exposure to damaging agents.

\section{"Diet-gene" interaction: the case of "zinc-zinc related genes" in the context of healthy lifespan and longevity}

Up to $25 \%$ of the variation in human lifespan is heritable [101]; the rest is due to environmental and life style factors, which impact the ageing process contributing as such to a large inter-individual variability. Therefore, current problems are to understand how the genetic factors influencing ageing and longevity are predicted to respond to fluctuating environments. Among environmental factors, nutrition plays a very important role in view of its high impact on gene expression, protein production and epigenetic mechanisms implicated in regulating the life span [96]. Despite the exact contribution of nutrition to human longevity remains unknown, some dietary patterns with likely different impact on long-term disease occurrence and survival have been identified. In this context, strong evidence for a beneficial effect of higher conformity with the "Mediterranean" dietary pattern on causes of death, including those ones by cardiovascular diseases and cancer, has been reported [83, 102].

By the other side, it is also commonly accepted that the complex interactions of multiple polymorphisms play a key role in how individuals may respond to dietary interventions [38]. For each nutrient, there is a window of intake between the Recommended Dietary Allowance (RDA), (which is defined as the dietary intake sufficient to meet the requirement of $97 \%$ of healthy individuals in a particular stage of life and sex group), and the tolerable upper limit (UL), which is the highest nutrient intake that can be achieved without incurring risk of adverse health effects for most individuals in the general population [140]. Although worldwide research on genetic variation that 
requires a different RDA or UL is still in progress, several genes and alleles have been suggested to affect nutrient utilization, including genes involved in the metabolism of folate and vitamin B-12 [60, 62, 91], lipids [61, 74] alcohol [20], lactose [142], iron [46, 77] and zinc [31, 97]. In the context of healthy lifespan and longevity, nutrigenetic and nutrigenomic implications around this last nutrient (zinc) appear very important taking into account that: (1) RDA $(11 \mathrm{mg} /$ day for men and $8 \mathrm{mg} /$ day for women) and UL (40 $\mathrm{mg} /$ day for adults) for zinc are very close [50]; (2) About $10 \%$ of the human proteome consists in potential $\mathrm{Zn}$ binding proteins [5]; (3) Proteins devoted to $\mathrm{Zn}$ transport (ZnT) and buffering, most of which display functional polymorphic sites, include at least ten members of the $\mathrm{ZnT}$ family [134], 15 members of the ZIP family (i.e. Zn-regulated metal transporter, iron-regulated metal transporterlike protein) [36, 134] and ten distinct isoforms of MT [150]; 4) zinc is an essential micronutrient strictly involved in regulating gene expression [35], inflammatory response $[63,124]$ and antioxidant activity [125].

Therefore zinc may be of relevance in the interaction with some genes especially involved as transcriptional factors in the expression of pro-inflammatory cytokines (IL-6, TNFalpha) and heat shock proteins (HSP70). Since many transcriptional factors are encoded by zinc finger motifs [41], the relevance of zinc is strengthen. Old subjects genetically predisposed to a dysregulation of the inflammatory/immune response display usually a mild zinc deficiency [107], suggesting that polymorphisms of IL-6, TNF- $\alpha$ and Hsp70 may be useful tools for screening old subjects with a likely different dietary requirement of zinc and, at the same time, for screening subjects who effectively need zinc supplements.

Moreover, although the plasma zinc concentration of nonagenarians is still significantly depressed, the neutrophil $\mathrm{Zn}$ content and $\mathrm{Zn}$-dependent active plasma thymulin levels are normal [110] suggesting a preserved intracellular $\mathrm{Zn}$ bioavailability in these very old individuals. Within this scenario, zinc-gene interaction may play a crucial role in longevity, taking also into account that the favourable genetic background of nonagenarians/centenarians can help these individuals to maintain some indexes of the zinc status within the normal range.

In the following paragraphs, we report the studies carried out on some polymorphisms of genes related to inflammatory/stress response, their possible interaction with zinc metabolisms as well as their implications for healthy ageing and longevity.

\section{Zinc-MT gene interaction}

Metallothioneins are essential to intracellular zinc homeostasis by sequestration and release of the metal at the occurrence and thereby controlling available free zinc ions [119]. The cysteine sulphur ligands in the cluster structure of MTs can be reduced (zinc sequestration) or oxidized (zinc release) with thus concomitant changes in the relative amount of bound and free zinc [93]. MTs are genetically polymorphous protein families with subfamilies, subgroups and various isoforms. Humans possess genes for four subfamilies (encoded by at least ten functional MT genes), all located in the chromosome 16: the brain specific MT-3, the squamous epithelium specific MT-4 and the ubiquitous MT-1 and MT-2 [147, 155].

One of the first functions of MT-I and MT-II is to regulate zinc homeostasis and to limit oxidative damage within the cells [119]. Following an injurious stimulus, such as a transient inflammation, the subsequent oxidative stress induce the release of zinc from MTs via NO, in order to promote the activity and expression of antioxidant enzymes, including MT itself, thus reducing the oxidative damage and the consequences of the injurious stimulus [138]. However, the increased expression of pro-inflammatory cytokines occurring in ageing, leads to increased expression of MTs, which in turn sequester considerable amount of zinc making it less available for an efficient immune response [104].

If, on one side, the reduced zinc ion availability in old age might indicate an excessive sequestration of zinc ions by MTs, on the other side, consideration of recent findings on oxidative modification of MTs leading to their loss of function suggests also a mechanism whereby these proteins can also loose their ability to buffer the intracellular free zinc concentration $[10,66]$. In this case, MTs would be unable either to bind or to consequently release zinc in response to stressors. However, it is still unclear if dysfunctional MTs can be considered a typical alteration associated with specific disease/disorders, such as hyperhomocysteinemia and type 2 diabetes, or if they are a common feature of ageing. Anyway, as a consequence of the altered zinc metabolism, also a large number of genes that act as zinc sensors and transcriptional activators and/or repressors are altered in ageing [55]. This may have a deep impact on the regulation of zinc dependent transcription factors, because they, not only regulate "zinc sensitive" genes, but also control their own transcription through positive auto regulatory mechanisms [90].

Taking into account that healthy centenarians display a low MT expression and satisfactory zinc ion availability despite pro-inflammatory cytokines (IL-6, TNF- $\alpha$ ) increases [105], it may be suggested that this feature reflects the existence of compensatory phenomena able to counteract the effects of inflammation in these exceptional individuals. Moreover, these data suggests that a preservation of zinc homeostasis is an important feature of healthy centenarians. Therefore, the role played by the zinc-gene 
interaction is pivotal to reach successful ageing and, at the same time, to escape some age-related diseases. Since, the persistence of inflammatory stimuli over time represents the biological background favouring the susceptibility to age-related diseases/disabilities, the absence of specific "robust" gene variants and/or the presence of specific "frail" gene variants might predict, on one hand the longevity, on the other hand the predisposition to the appearance of the more common age-related diseases, such as infections and cardiovascular diseases. In this context, it has to be considered that genes selected, because they confer a reproductive advantage early in life, may have dangerous effects in the post-reproductive period. In fact, negative selection against these harmful effects fails due to the decline of natural selection with age. This fact means that one gene that is "favourable" in young/adult age may be "disadvantageous" in ageing (antagonistic pleiotropy theory of ageing) [156].

Following this perspective, the beneficial effect of inflammation, via an optimal MFT-1-MT-zinc-gene interaction, in young and adult age may become detrimental in old age [104]. The recent discovery of novel polymorphisms of MT2A and MT1A supports this assumption. Indeed, old subjects carrying AA genotype for MT2A polymorphism display low zinc ion bioavailability, chronic inflammation by high IL-6 and altered lipid assessments, with subsequent elevated risk for atherosclerosis and diabetes type II [57]. By contrast, polymorphism corresponding to A/C (Asparagin/ Threonin) transition at $+647 \mathrm{nt}$ position in the MT1A coding region is the most involved in the women longevity [34].

We report in the next chapters the allelic variants of proinflammatory cytokines (IL-6 and TNF- $\alpha$ ) and heat shock protein (HSP70) in relation to the gene expression of MTs, zinc ion bioavailability and innate immunity as possible predictive factors for the longevity in Italian-aged population. Moreover, such allelic variants may be very useful tools in order to screen old subjects at risk for zinc deficiency on genetic basis, taking into account that the actual methodological procedures to test the "zinc status" are often misleading and that laboratory investigations to assay zinc ion bioavailability are scarcely reproducible and poorly applicable to clinical practice $[65,103]$. In this context, a novel reproducible system in testing intracellular zinc ion bioavailability has been developed using zinc fluorescent probe (Zynpir-1) associated with MT values, representing both tests valid methods to detect the intracellular zinc status [92].

\section{Zinc-Interleukin-6 gene interaction}

Interleukin-6 is a pleiotropic cytokine capable of regulating proliferation, differentiation and activity of a variety of cell types and plays a pivotal role in immune response [68]. In particular, the most important function of IL-6 is most likely as a mediator of the acute phase inflammatory responses. These include the balance of the pro-inflammatory/anti-inflammatory pathways, lymphocytes activation and hepatocellular stimulation of acute phase protein synthesis [43]. Studies of the effects of ageing on inflammatory response show interleukin-6 (IL-6) to be an important "cytokine for gerontologists" [42, 72]. Indeed, an age-related increase of IL- 6 concentrations has been found in serum, plasma and supernatants of mononuclear blood cell cultures from elderly people devoid of any overt age-related diseases [44, 45], beginning as early as 30-40 years of age [111] and being prominent among men [160] and in centenarians [8]. Recent evidences have shown that abnormal increased concentrations of IL- 6 are reliable markers for functional disability and predictor of disability and mortality among the elderly [47]. Moreover, IL-6 dysregulation is involved in age-related diseases, such as cancer, lymphoma, cardiovascular diseases, osteoporosis, Alzheimer's diseases, diabetes and atherosclerosis [78, 81, 131], which in turn have a substantial inflammatory pathogenesis [30, 37].

The human IL-6 gene is located on chromosome $7 \mathrm{p} 21$ and consists of five exons and four introns [133, 157, 161]. Genetic studies have identified four polymorphisms in the promoter region of the IL-6 gene $(-597 \mathrm{G} / \mathrm{A},-572 \mathrm{G} / \mathrm{C}$, $-373 \mathrm{~A} / \mathrm{T},-174 \mathrm{G} / \mathrm{C}$ ) that have significant effect on IL-6 expression in an in vitro system [80, 116, 117]. A variable number of tandem repeat (VNTR) polymorphisms were found in the $3^{\prime}$ flanking region of the IL- 6 gene (C allele) [9]. In humans, a polymorphism in the IL-6 promoter (A/C polymorphism at position -174) altered IL-6 gene transcription rates in vitro [48] and IL-6 levels in vivo [145]. In this last paper, people carrying CC or GC genotypes are defined as $\mathrm{C}+$, while those carrying $\mathrm{GG}$ genotypes are indicated as $\mathrm{C}-$.

It has been suggested that IL- $6-174 \mathrm{G} / \mathrm{C}$ locus variability is capable of modulating on one hand the individual susceptibility to common causes of morbidity and mortality among elderly, on the other hand it may play a crucial role in longevity [53]. Therefore, the genetic variations of this locus of IL- 6 gene are fundamental in elderly population in order to better understand the intrinsic causes of the longevity. The association of these genetic variations to the possible different immune responses is an attractive focus in elucidating the molecular mechanisms involved in immunosenescence.

The genetic variations of the IL- $6-174 \mathrm{G} / \mathrm{C}$ locus have been extensively studied by different groups with, however, contradictory data. Bonafe et al. [18] studied IL-6 promoter genetic variability at the $-174 \mathrm{C} / \mathrm{G}$ locus and its effect on IL-6 levels in Italian 700 people aged 60-110 
years, including 323 centenarians. Individuals who are genetically predisposed to produce high levels of IL-6 during ageing, i.e. $\mathrm{C}-$ men (GG genotype) at IL-6 - $174 \mathrm{C} / \mathrm{G}$ locus, are disadvantaged for longevity. On the other hand, the capability of $\mathrm{C}+$ individuals ( $\mathrm{CC}$ and $\mathrm{CG}$ genotypes) to produce low levels of IL-6 throughout life span appears to be beneficial for longevity, at least in men. The women have, conversely, high IL-6 serum levels later in life with respect to men independently from $-174 \mathrm{C} / \mathrm{G}$ locus polymorphism [18].

The inhibitory tone of estrogens on IL-6 gene expression could explain the gender difference [23], assuming that its long-term effects last until the extreme limits of human life-span.

The major production of IL-6 in C- subjects for the whole life, including centenarians, has been also confirmed by in vitro studies [114] and by other in vivo longitudinal studies carried out in Irish old and nonagenarian people [129]. Modest, but significant implication of interleukin-6 promoter polymorphisms in longevity was also reported in Danish people [32]. Other studies in old and nonagenarian Finnish [152] as well as in a limited number of old and nonagenarian Southern Italian individuals [28] found that the allelic variations in $-174 \mathrm{G} / \mathrm{C}$ locus are not involved in the longevity and are gender independent. However, when the distribution of other germ-line variants of stress response genes, such as tyrosin hydroxylase was studied, a similar male-specific difference between young people and centenarians were observed [39]. In addition, a more recent study in old and nonagenarian subjects has confirmed that IL-6 production is higher in $\mathrm{C}$ - carriers and that these subjects are prone to contract one of the more usual agerelated inflammatory pathologies, such as atherosclerosis [56]. Interestingly, in this last study $\mathrm{C}$ - old and nonagenarian subjects display also impaired innate immune response (NK cell cytotoxicity) coupled with increased MTs, zinc deficiency and low zinc ion bioavailability in comparison with $\mathrm{C}+$ carriers [56]. A functional implication of the IL-6 -174G/C locus on MT expression and zincregulated genes has been also recently confirmed by targeted studies with in vitro zinc supplementation [98] as well as in vivo [95, 108].

As reported above, high IL-6 in elderly induces abnormal increments of MTmRNA expression which leads to low zinc ion bioavailability because of a very limited capacity in zinc release by $\mathrm{MT}$ in chronic inflammation [104]. This phenomenon causes an impaired immune response due to the relevance of zinc in immunity [103].

These findings clearly suggest that the genetic variations of the IL-6 - 174G/C locus play a key role for the longevity also at functional level and confirm the existence of a major number of centenarians with $\mathrm{C}+$ carriers than $\mathrm{C}-$, as previously found by Bonafe et al. [18]. In this context, an intriguing point is related to the low expression of the signal transducing component (gp130) of IL-6 receptor in centenarians in comparison with elderly despite high circulating levels of IL-6 [110], which in turn may be inactive in centenarians [105]. Therefore, the inflammatory status is not so detrimental in very old age as, in contrast, occurring in normal ageing. As a consequence, MTmRNA is lower and the zinc ion bioavailability is satisfactory for the immune efficiency in very old age [105]. So in ageing population, the individuals who are $\mathrm{C}-$ carriers, display high gp130 and have the tendency to produce elevated IL-6 quantities and therefore disadvantaged to reach the goal of extreme longevity. This fact leads to an increased proneness in developing some age-related inflammatory diseases, such as atherosclerosis, through an altered zincMT-immune/inflammatory interplay.

However, the discrepancy among all the genetic studies on the variations of the IL- $6-174 \mathrm{G} / \mathrm{C}$ locus in relation to the longevity in elderly is still unclear. The ethnic differences, lifestyle and cultural differences among these populations, could also play a role, as well as other undefined factors. Large-scale studies at European level, on many ethnic populations are needed to clarify this important topic. For this reason, Zincage project has been developed and the clarification of this point has been one of the tasks of the project. A possible rationale behind these conflicting data has been given taking into account the different intake of zinc between Northern and Southern European countries. In other words, the studies performed in northern European populations report that $\mathrm{C}-$ allele might not be any more the "risk allele". This fact can be at least partially explained by the higher zinc intake in these populations [108]. Moreover, the determination of the genetic variations of the IL-6 - 174G/C locus associated to a dietary assessment or to a comprehensive evaluation of the zinc status has been reported as an useful strategy to identify old subjects who can benefit of zinc supplementation without health risks.

\section{Zinc-TNF- $\alpha$ gene interactions}

$\mathrm{TNF}-\alpha$ is a pleiotropic inflammatory cytokine mainly produced by macrophages and T-cells [151]. TNF- $\alpha$ stimulates the proliferation of normal cells, exerts cytolytic or cytostatic activity against tumour cells and causes inflammatory, antiviral and immunoregulatory effects [132]. TNF- $\alpha$ is an acute phase protein, which initiates a cascade of cytokines and increases vascular permeability, thereby recruiting macrophage and neutrophils to the site of infection [151]. Without $\mathrm{TNF}-\alpha$, mice infected with gram-negative bacteria experience septic shock [73]. An interesting aspect of $\mathrm{TNF}-\alpha$ functional properties is its 
peculiar interaction with IL- 6 . TNF- $\alpha$ constitutes a direct and important stimulator of IL-6 production, via NF-kB [149], thereby recruiting leukocytes to the site of infection. At the same time with a paracrine influence, IL-6 inhibits the synthesis of TNF- $\alpha$ stimulating the production of antiinflammatory cytokine (IL-10) and inducing the shedding of TNF receptors that secondly bind and suppress the function of circulating TNF- $\alpha$ [27, 88, 146]. As a consequence, the balance between proinflammatory and antiinflammatory cytokines is fundamental in controlling the magnitude of the inflammatory response. An impaired response results in immunodeficiency leading to infection and cancer, whereas excessive response causes morbidity and mortality in diseases such as atherosclerosis, diabetes, Alzheimer's disease, autoimmune diseases and septic shock during acute infections [147], which are pathologies with a great inflammatory pathogenesis [30, 37]. In ageing, substantial increments of TNF- $\alpha$ concentrations as well as of IL-6 occurs, whereas IL-10 levels are low [24] leading to a complete dysregulation of the balance anti/pro-inflammatory cytokines with the subsequent appearance of chronic low-grade inflammatory activity and the risk to contract age-related diseases [22]. Different longitudinal studies in cohorts of old people from some European countries (Finland and Denmark) as well as from USA have shown that abnormal increments of TNF- $\alpha$ are predictors of mortality and act as a marker of the frailty syndrome, suggesting a pivotal role of this cytokine in controlling the magnitude of the inflammatory status in ageing and in very old age [25]. Circulating TNF- $\alpha$ levels are regulated at different stages: gene transcription, posttranscription control of mRNA stability, cleavage of membrane-associated TNF- $\alpha$ to induce its bioactive soluble form, and expression of TNF receptors [64]. Genetic variations located within TNF promoter region influence the susceptibility to age related diseases by increasing gene transcription and consequently cytokine production $[16,121]$. The TNF gene cluster is located on human chromosome $6 \mathrm{p} 21$ within the class III region of the major histocompatibility complex [153]. Several single nucleotide polymorphisms (SNPs) have been identified in the human TNF- $\alpha$ gene promoter. One of them is a guanine $(\mathrm{G})$ to adenine (A) transition at position -308 that generates the TNF1 and TNF2 alleles, respectively. The TNF2 allele is associated to high in vitro TNF- $\alpha$ gene expression, and it has also been linked to an increased susceptibility and severity of a variety of illnesses, such as rheumatoid arthritis, systemic lupus erythematosus, inflammatory bowel disease and Alzheimer's type dementia. It is also associated with a higher septic shock susceptibility and mortality [71]. Therefore, the investigation of polymorphisms within the TNF- $\alpha$ cluster is important in understanding the role of TNF- $\alpha$ regulation in specific diseases [1]. For this reason, the -308 G/A SNP has been the most studied polymorphism also in relation to ageing and longevity, taking into account that high levels of TNF- $\alpha$ are the major cause of frailty and disabilities in normal ageing as well as in older individuals (octogenarian/nonagenarian) [85]. Studies on various cytokine polymorphisms in a Finnish [152] and a Danish [25] population, including TNF- $\alpha-308 \mathrm{G} / \mathrm{A}$ locus, have shown that there was no differences in the TNF- $\alpha-308 \mathrm{G} / \mathrm{A}$ promoter polymorphism between octogenarians, centenarians and young controls, suggesting that the allelic variations of various genotypes within the TNF- $\alpha-308 \mathrm{G} / \mathrm{A}$ promoter are not linked with longevity. Recent studies performed in Italian old population, including 35 healthy nonagenarians, have confirmed the existence of no differences in $\mathrm{A}+$ and $\mathrm{A}-$ carriers ( $\mathrm{AG}$ and $\mathrm{AA}$ genotypes, called $\mathrm{A}+$; and $\mathrm{GG}$ genotype, called $\mathrm{A}-$ ) between adult, old and nonagenarian subjects, with also no differences in TNF- $\alpha$ gene expression and circulating levels between old and very old individuals [33]. However, a single study performed in Italian old population has shown that the interaction between TNF- $\alpha-308$ promoter SNP and IL-10 -1082 promoter SNP is related to longevity [89]. In particular, the evaluation of combined IL-10 and TNF- $\alpha$ genotypes showed that there was a significant increase of the "antiinflammatory" (IL-10 - 1082GG/TNF- $\alpha-308 \mathrm{GG}$ ) genotype in centenarians men over controls [89].

Moreover, studies in patients affected by severe infections or septic shock have highlighted the prognostic value of TNF- $\alpha-308$ promoter SNP [71]. Studies performed in children with meningococcal disease [112], in patients with septic shock [100, 141], in old septic shock patients [143], and more recently in old patients affected by severe bronchus-alveolar infections [33], show that the TNF- $\alpha$ $-308 \mathrm{~A}$ allele $(\mathrm{A}+$ carrier $)$ is associated with adverse outcome with respect to TNF- $\alpha-308 \mathrm{~A}$ allele (A- carrier). Moreover, patients with $\mathrm{A}+$ carrier have less responsiveness to drugs and significantly increased risk of death [120]. All these findings suggest that of TNF- $\alpha-308 \mathrm{G} / \mathrm{A}$ SNP is pivotal for the outcome in a variety of infectious and inflammatory diseases.

An interesting point is also the association between TNF- $\alpha-308$ G/A SNP polymorphism and innate immune response (NK cell cytotoxicity), stress related proteins (MTs) and nutritional factors (zinc). Although no differences exist both in TNF- $\alpha$ gene expression and circulating levels between old and nonagenarian subject [33], significant increments appear in MT gene expression and decrements in NK cell cytotoxicity and zinc ion bioavailability in $\mathrm{A}+$ carriers than $\mathrm{A}-$ ones. These differences are more pronounced in old $\mathrm{A}+$ patients affected by severe infections [33]. For the concepts expressed above regarding the role of high MT in chronic inflammation [104] and 
taking into account that the TNF- $\alpha-308 \mathrm{G} / \mathrm{A}$ SNP plays a role in innate immune response and in regulating IL-10 expression, the determination of TNF- $\alpha-308 \mathrm{G} / \mathrm{A}$ SNP may be considered as an useful tool to screen old subjects at risk for zinc deficiency. On the other hand, it has been reported that zinc down-regulates the inflammatory cytokines, including $\mathrm{TFN}-\alpha$, through an up-regulation of the zinc finger protein $\mathrm{A} 20$, and subsequent inhibition of $\mathrm{NF}-\mathrm{kB}$ [126].

\section{Zinc-HSP70 gene interaction}

Heat shock proteins are molecular chaperones and are present in both prokaryotic and eukaryotic cells. They are present in the cytosol, mitochondria, endoplasmic reticulum and nucleus [70]. The principal HSPs range in molecular mass from 15 to $110 \mathrm{kDa}$ and are divided into groups based on both size and function [154]. The most well-studied HSPs in mammals are those with molecular weight masses of $60,70,90$ and $110 \mathrm{kDa}$. They are expressed at euthermic body temperatures $\left(37^{\circ} \mathrm{C}\right)$ and in condition of stresses such as heat shock, infection, inflammation, exposure of the cell to toxins, starvation and hypoxia. Their high levels of conservation suggest that they play an important role in fundamental cell processes: from an antiapoptotic role to protein folding, to protein degradation, to protein intracellular trafficking and cytoprotection [109, 154]. The latter property occurs in a wide variety of human diseases, including ischaemia, inflammation, cancer, as well as metabolic and neurodegenerative disorders [158].

HSP70 family appears to be the most temperature sensitive, evolutionary preserved and distributed in all animal species and the most highly conserved among the Hsps [122]. Three genes located in chromosome 6p21 encode members of HSP70 protein family: HSP70-Hom, HSP70-1 and HSP70-2. The first one is expressed constitutively, whereas HSP70-1, and HSP70-2 codify an identical protein and are the major inducible forms [99]. HSP70 plays a role in the assembly and transport of newly synthesized proteins within the cells as well as in the removal of denaturized proteins. HSP70 is hyperactivated in presence of noxious stimuli, such as heat, oxygen stress and infection, in order to protect cells from apoptosis [14] via inhibition of caspase-3 [87]. In vitro study on human fibroblasts undergoing ageing shows that the increment of HSP70 expression is associated with improved functional and survival ability of the cells in terms of increased proteasome activities, increased ability to decompose $\mathrm{H}_{2} \mathrm{O}_{2}$, reduced lipofuscin accumulation and enhanced resistance to ethanol, $\mathrm{H}_{2} \mathrm{O}_{2}$ and UV radiation [49]. An overexpression of HSP70 contributes to extend longevity in non-mammalian organism [2, 159]. However, old rats show reduced expression and induction of heat shock proteins in response to physiological stresses, including hypertemia [118]. In humans, the ageing process is associated with elevated morbidity and mortality rates due also to reduced thermotollerance [135]. On the other hand, old humans display reduced Hsp70 activity with subsequent reduced ability to respond to stress, including heat exposure [79, 137]. Conversely, it has been reported that the heat induction of HSP70 in EBV transformed B-lymphocytes from centenarians is similar to the one observed in young/ adult cells [4, 94]. Although in both studies the sample size was small to draw any definitive conclusion, especially for males, there is an interesting concordance between these results and previous observations on a possible genderdependence. One of these study [94] investigated the HSP70 production under the influence of the (A/C) - 110 HSP70-1 polymorphism, which has been previously reported to affect the chance to attain longevity in females [3]. The results confirmed that lines obtained from carriers of A allele, which is unfavourable to longevity in women [3], had a trend in reduced HSP70 synthesis and production with respect to lines obtained from carriers of $\mathrm{C}$ allele, and this difference was more evident in females than males. The origin of this gender dependence is still unknown but it could be one of the reasons why female centenarians are predominant. If on one side, the comparison between age-classes can be affected by the loss of the age-related phenotypes during the process of immortalization, on the other side the immortalization should not overrun or abrogate functional genetic differences in the individuals from whom the cell lines derive. In fact, the same model of immortalized cells was successfully used to evaluate the functional implications of the -174 IL-6 polymorphism [115].

Overall, these studies suggest that centenarians are more capable to protect more efficiently their cells from damage accumulation and subsequent cell dysfunction associated with ageing. This major capacity may be largely due to a good zinc ion bioavailability, via MTs homeostasis, occurring in centenarians [105]. Indeed, short term zinc supplementation resulted in a marked increase in both basal and stress-induced HSP70 levels in lymphocytes from healthy old donors [127].

These findings corroborate in vitro experiments that reported a stress response inducing property of zinc in various peripheral cells of different origin [4, 13, 67], suggesting that zinc "per se" may exert a mild stress on a variety of cell types. This property of zinc might resemble an hormetic action [128]. In fact, the zinc supplementation in elderly subjects elicits a more intense stress response (twofold to fourfold increase of heat-induced HSP70) with no apparent damage [127].

Among the properties of HSP70, recent studies have ascribed novel functions to the Hsp70 protein depending on 
its localization. Surface-bound HSP70 specifically activate NK cells, while HSP70 released into the extracellular milieu specifically binds to Toll-like receptors 2 and 4 on antigen-presenting cells and exerts immunoregulatory effects, including upregulation of adhesion molecules, costimulatory molecule expression and cytokine and chemokine release [6, 7]. Therefore, in contrast to its intracellular role, extracellular HSP70 can produce deleterious effects mainly attributed to the stimulation of a potent pro-inflammatory response through the release of pro-inflammatory cytokines, nitric oxide and stimulation of innate and adaptive immunity. Studies performed in centenarians and centenarian offspring demonstrate that both these individuals have significantly lower HSP70 serum levels than unrelated controls [144]. Following these studies, long-lived individuals may have less cellular stress and, at the same time, decreased exposure to inflammation because of lower extracellular HSP70 levels [144]. However, further investigations are required in order to clarify why centenarians and centenarian offspring have lower levels of serum HSP70 and to better understand the role played by zinc and genetic polymorphisms in this observation. At our knowledge, there is an isolated study investigating the role of 1267 HSP70-2 polymorphisms and zinc status on the risk of coronary artery disease [58]. This study reported an association of 1267 HSP70-2 polymorphism with coronary artery disease, but the zinc status (plasma and $\mathrm{Zn} / \mathrm{Fe}$ ratio in erythrocytes) was not affected by the polymorphism.

Thus, we can conclude that nutritional zinc can highly affect HSP70 expression and induction but, conversely, no evidences for an interaction between HSP70 gene variants and dietary requirements of zinc are still available.

\section{Ageing, diseases, SNPs: is it better to test single polymorphism or more polymorphisms associated to environmental factors (nutritional factors and life style)?}

The ageing process and the most common age-related diseases display multiple genetic variants and environmental variables contributing to the observed phenotype. Because of the multi-factorial nature of genes-environmental interactions, each individual genetic variant has generally only a modest effect, and the interactions of genetic variants with each other or with environmental factors can potentially be important in determining the observed phenotype. Recent evidences suggest that the combinations of more genetic variants may better explain some of the inherited variation in susceptibility to common age-related diseases [113]. Genetic association studies, in which the allele or genotype frequencies at markers are determined in old individuals or in patients affected by various diseases and compared with those of controls (healthy individuals or individuals with exceptional longevity like nonagenarian/centenarians), may be an effective approach to detect the effects of genetic variants with modest effects. With the recent explosion in SNP discovery and genotyping technologies (array), large-scale association studies have become feasible [29].

In this context, studying the interactions among more polymorphisms rather than a SNP is a power genetic approach in order to discovery more "robust" genes related to the longevity or the appearance of age-related diseases [15]. However, the study of a large number of genes is impracticable because hundreds of thousands of SNPs may need to be simultaneously analysed in order to warrant the goal of finding "robust" genes for the longevity. Therefore, it is necessary to have valid tools for large-scale gene investigations, such as whole-genome SNPs association maps, which can help to bring down the number of testable SNPs. A first generation of whole-genome association maps, developed using Linkage Disequilibrium (LD) analysis between common polymorphisms, should be available but still under development [29]. LD describes the non-random correlation between alleles at a pair of SNPs without a hierarchical structure to the linkage [162]. LD analysis generally identifies more than 30,000 of candidate genes for a specific pathology and evidences the major risk alleles [139]. Although this analysis is very suggestive and likely gives a clear identification of potential candidate genes for a single pathology, as suggested for instance in cancer [21], it still in infancy because of the presence of many genes with modest effects [17]. Thus, many efforts are actually in progress in order to separate "robust" genes from "modest" genes. However, recent comparative genomic studies have demonstrated that evolutionarily conserved genes can be easily associated especially when these genes are involved in the same regulatory biological network. For instance, this is the case of genes involved in blood coagulation factors [26]. Moreover, the addition of intermediate phenotype analysis (enzyme analysis or immune response) and environmental factors (nutritional factors and life style) that can affect the genes, give a more complete picture of the possible candidate genes as "robust" genes involved in a specific pathology or physiological condition. This is the case reported in the examination of the genetic variants of PON-1 locus, where none of the SNPs examined showed significant associated risk for carotid artery disease (CAAD) directly [75]. The addition of the intermediate phenotype (enzyme activity) helped in the identification of a group of SNPs that probably do have a small effect on CAAD risk, but a risk not likely identifiable in the analysis of the single polymorphisms [76]. Also the interaction among various 
polymorphisms of anti/pro-inflammatory cytokines, such as IL-10 and TNF- $\alpha$, helped in the identification of IL-101082GG/TNF- $\alpha-308$ GG genotype interaction as relevant for the longevity rather than the single polymorphism of IL-10 or TNF- $\alpha$ [89]. The same conclusion as high risk factor for mortality due to sepsis and infections has been reported when HSP70-2A and TNF- $\beta 2$ genotypes are associated [141]. All these findings therefore highlight the importance of knowing all the polymorphisms relevant to the inflammatory response in individuals rather than interpreting a polymorphism in isolation. With regard to the polymorphisms of cytokines (IL- 6 and TNF- $\alpha$ ) and heat shock proteins (HSP70-2) reported in this review, the interactions among different polymorphisms was considered because these genes are all evolutionary conserved and involved in the same regulatory network: i.e. the control of the magnitude of the inflammatory status both in ageing and in age-related diseases (infection and atherosclerosis). In this context, some polymorphisms of MT (isoform I and II) have to be included in the network, taking into account that MTs homeostasis is also involved in the longevity of worm Caenorhabditis elegans [11]. Recent data from our laboratory show for the first time that a polymorphisms of MTs is involved in longevity [34], whereas MT2A polymorphism is involved in atherosclerosis worsening [57]. Moreover, the addition of some intermediate phenotypes (i.e. innate immune response like NK cell cytotoxicity), and environmental factors, such as zinc ion bioavailability and life style, may likely give a more complete picture of the influence of the genes related to inflammation on the longevity and on the appearance of age-related diseases. Studies on these interactions are strongly encouraged in order to find "robust" gene networks in the human genome associated with longevity, other than to a single pathology [29], and to explain the contradictory data reported for some genetic factors.

\section{Conclusions}

In this paper, we reviewed data regarding to the pivotal role played by the zinc-gene interaction in affecting some relevant cytokines (IL-6 and TNF- $\alpha$ ) and heat shock proteins (HSP70-2) in ageing, successful ageing (nonagenarians) and the most common age-related diseases, such as atherosclerosis and infections. The polymorphisms of the genes codifying these proteins are predictive on one hand in longevity, such as IL-6 - 174G/C locus, confirming previous report by [18], on the other hand the same IL-6 polymorphism together with 1267 Hsp70-2 polymorphism are associated to cardiovascular diseases. TNF- $\alpha-308 \mathrm{G} / \mathrm{A}$ is instead more related to risk of severe infection than longevity. Taking into account that the genetic longevity is a very complex and quite peculiar phenomenon being affected by life style and environmental factors, the analysis of this polymorphism in association to some functional parameters (innate immune response, such as NK cell cytotoxicity) and environmental factors (nutritional factors, such as zinc) gives a more complete picture of role played by these polymorphisms in longevity and in the arising of age-related diseases, indicating these genes as possible "robust" genes. Indeed, all these polymorphisms are associated with chronic inflammation, low zinc ion bioavailability, depressed innate immune response and high gene expression of MTs, which may be implicated in a lower zinc ion availability necessary for an optimal innate immune response. Therefore, the immune plasticity that is a condition "sine qua non" in order to reach successful of ageing [54, 106], is strictly linked to the magnitude of inflammatory status and to zinc-genes (IL-6, TNF- $\alpha$, Hsp70) interaction, where MT homeostasis and its polymorphisms can also play a pivotal role (Fig. 1). For this purpose, within the framework of Zincage project (www.zincage.org) a large number of elderly subjects from different European Countries [SUD (Italy, Ancona and Bologna; Greece, Athens;) and NORD (Poland, Lodz; Germany, Aachen and France, Besancon) Europe] has be screened for the risk to develop zinc deficiency studying the interactions of IL- $6-174$ and MT1A +647 polymorphisms associated with biochemical and immune parameters as well as dietary habits. The data have been compared with those obtained from nonagenarians (from different European Countries) and old patients affected by

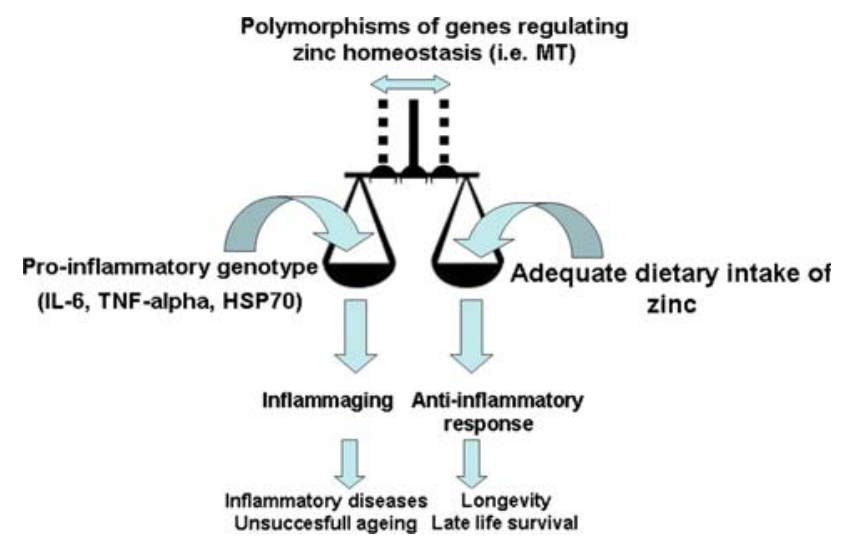

Fig. 1 The interaction between zinc dietary intake and some genes regulating the inflammatory response and zinc homeostasis for healthy ageing and longevity: Polymorphism of genes involved in regulating zinc hoemostasis (i.e. MT) can be schematically represented as the hinge of the balance that determine the adequate dietary intake of zinc necessary to counterbalance the weight of proinflammatory genes. An high inflammatory response can result detrimental in ageing leading to increased susceptibility to inflammation-based diseases later in life. On the other side, feeding the body with the adequate requirement of zinc can result in a proper antiinflammatory response which may be pivotal to reach longevity 
severe infections and atherosclerosis. The main results of the project confirmed a strong contribution of MT genetic variants in regulating zinc homeostasis and perhaps its dietary requirements as well as their relevance in longevity and in some age-related pathologies [34, 57, 95, 98]. Moreover, it has been confirmed that IL-6 -174 polymorphisms can be used to identify old subjects with higher risk to develop zinc deficiency [98, 108]. The study revealed also that contradictory data existing on the association between IL-6 -174 polymorphisms and chronic disease can find a rationale in the different dietary intake of zinc existing in the different population studied [108]. Finally it is important to conclude considering an important aspect of zinc homeostasis which, in our opinion, will have profound implications for the individual zinc dietary requirements and propensities to develop particular agerelated disease. We refer to the zinc transporters cited above (paragraph 2). In fact, although nothing has been yet done on $\mathrm{Zn}$ transporters and ageing, there is a good evidence that they are involved in chronic disease and inflammation [40]. Consideration of recent developments in our understanding of the genetic basis of type 2 diabetes [36] and CAAD [59] provides strong examples of the potential relevance of zinc transporter polymorphisms to important age-related diseases. In view of these results we can anticipate that genetic of zinc transporters will be likely critical to most, if any, explanation of differences in zinc availability and inflammatory response between successful and normal ageing.

Acknowledgements Supported by INRCA and European Commission (Zincage project, contract n. FOOD-CT-2004-506850; Coordinator: Dr Eugenio Mocchegiani).

\section{References}

1. Aguillon JC, Cruzat A, Cuenca J, Cuchacovich M (2002) Tumor necrosis factor alpha genetic polymorphism as a risk factor in disease. Rev Med Chil 130:1043-1050

2. Aigaki T, Seong KH, Matsuo T (2002) Longevity determination genes in Drosophila melanogaster. Mech Ageing Dev 123:1531-1541

3. Altomare K, Greco V, Bellizzi D, Berardelli M, Dato S, DeRango F, Garasto S, Rose G, Feraco E, Mari V, Passarino G, Franceschi C, De Benedictis G (2003) The allele (A)(-110) in the promoter region of the HSP70-1 gene is unfavorable to longevity in women. Biogerontology 4:215-220

4. Ambra R, Mocchegiani E, Giacconi R, Canali R, Rinna A, Malavolta M, Virgili F (2004) Characterization of the hsp70 response in lymphoblasts from aged and centenarian subjects and differential effects of in vitro zinc supplementation. Exp Gerontol 39:1475-1484

5. Andreini C, Banci L, Bertini I, Rosato A (2006) Counting the zincproteins encoded in the human genome. J Proteome Res 5:196-201

6. Asea A (2003) Chaperokine-induced signal transduction pathways. Exerc Immunol Rev 9:25-33
7. Asea A, Kraeft SK, Kurt-Jones EA, Stevenson MA, Chen LB, Finberg RW, Koo GC, Calderwood SK (2000) HSP70 stimulates cytokine production through a CD14-dependant pathway, demonstrating its dual role as a chaperone and cytokine. Nat Med 6:435-442

8. Baggio G, Donazzan S, Monti D, Mari D, Martini S, Gabelli C, Dalla Vestra M, Previato L, Guido M, Pigozzo S, Cortella I, Crepaldi G, Franceschi C (1998) Lipoprotein(a) and lipoprotein profile in healthy centenarians: a reappraisal of vascular risk factors. FASEB J 12:433-437

9. Bagli M, Papassotiropoulos A, Knapp M, Jessen F, Luise Rao M, Maier W, Heun R (2000) Association between an interleukin- 6 promoter and $3^{\prime}$ flanking region haplotype and reduced Alzheimer's disease risk in a German population. Neurosci Lett 283:109-112

10. Barbato JC, Catanescu O, Murray K, DiBello PM, Jacobsen DW (2007) Targeting of metallothionein by L-homocysteine: a novel mechanism for disruption of $\mathrm{Zn}$ and redox homeostasis. Arterioscler Thromb Vasc Biol 27:49-54

11. Barsyte D, Lovejoy DA, Lithgow GJ (2001) Longevity and heavy metal resistance in daf- 2 and age-1 long-lived mutants of Caenorhabditis elegans. FASEB J 15:627-634

12. Barzilai N, Atzmon G, Schechter C, Schaefer EJ, Cupples AL, Lipton R, Cheng S, Shuldiner AR (2003) Unique lipoprotein phenotype and genotype associated with exceptional longevity. JAMA 290:2030-2040

13. Bauman JW, Liu J, Klaassen CD (1993) Production of metallothionein and heat-shock proteins in response to metals. Fundam Appl Toxicol 21:15-22

14. Beere HM (2001) Stressed to death: regulation of apoptotic signaling pathways by the heat shock proteins. Sci STKE 93:RE1

15. Bessenyei B, Marka M, Urban L, Zeher M, Semsei I (2004) Single nucleotide polymorphisms: aging and diseases. Biogerontology 5:291-303

16. Bidwell J, Keen L, Gallagher G, Kimberly R, Huizinga T, McDermott MF, Oksenberg J, McNicholl J, Pociot F, Hardt C, $\mathrm{D}^{\prime}$ Alfonso S (1999) Cytokine gene polymorphism in human disease: on-line databases. Genes Immun 1(1):3-19

17. Boffelli D, McAuliffe J, Ovcharenko D, Lewis KD, Ovcharenko I, Pachter L, Rubin EM (2003) Phylogenetic shadowing of primate sequences to find functional regions of the human genome. Science 299:1391-1394

18. Bonafe M, Olivieri F, Cavallone L, Giovagnetti S, Mayegiani F, Cardelli M, Pieri C, Marra M, Antonicelli R, Lisa R, Rizzo MR, Paolisso G, Monti D, Franceschi C (2001) A gender-dependent genetic predisposition to produce high levels of IL-6 is detrimental for longevity. Eur J Immunol 31:2357-2361

19. Bonafe M, Marchigiani F, Cardelli M, Olivieri F, Cavallone L, Giovanetti S, Pieri C, Marra M, Antonicelli R, Troiano L, Gueresi P, Passeri G, Berardelli M, Prolisso G, Barbieri M, Tesei S, Lisa R, De Benedictis G, Franceschi C (2002) Genetic analysis of Paraoxonase (PON1) locus reveals an increased frequency of Arg192 allele in centenarians. Eur J Hum Genet 10:292-296

20. Bosron WF, Li TK (1986) Genetic polymorphism of human liver alcohol and aldehyde dehydrogenases, and their relationship to alcohol metabolism and alcoholism. Hepatology 6:502510

21. Brennan P (2002) Gene-environment interaction and aetiology of cancer: what does it mean and how can we measured? Carcinogenesis 23:381-387

22. Bruunsgaard H, Krabbe K (2004) The clinical importance of proinflammatory cytokines in elderly populations. In: Straub $\mathrm{RH}$, Mocchegiani E (eds) The neuroendocrine immune network in ageing. Amsterdam, Elsevier, pp 383-395 
23. Bruunsgaard H, Pedersen AN, Schroll M, Skinhoj P, Pedersen BK (1999) Impaired production of proinflammatory cytokines in response to lipopolysaccharide (LPS) stimulation in elderly humans. Clin Exp Immunol 118:235-241

24. Bruunsgaard H, Pedersen M, Pedersen BK (2001) Aging and proinflammatory cytokines. Curr Opin Hematol 8:131-136

25. Bruunsgaard H, Andersen-Ranberg K, Hjelmborg JB, Pedersen BK, Jeune B (2003) Elevated levels of tumor necrosis factor alpha and mortality in centenarians. Am J Med 115:278-283

26. Butt C, Zheng H, Randell E, Robb D, Parfrey P, Xie YG (2003) Combined carrier status of prothrombin 20210A and factor XIIIA Leu34 alleles as a strong risk factor for myocardial infarction: evidence of a gene-gene interaction. Blood 101:3037-3041

27. Candore G, Lio D, Colonna Romano G, Caruso C (2002) Pathogenesis of autoimmune diseases associated with 8.1 ancestral haplotype: effect of multiple gene interactions. Autoimmun Rev 1:29-35

28. Capurso C, Solfrizzi V, D'Introno A, Colacicco AM, Capurso SA, Capurso A, Panza F (2004) Interleukin 6-174 G/C promoter gene polymorphism and sporadic Alzheimer's disease: geographic allele and genotype variations in Europe. Exp Gerontol 39:1567-1573

29. Carlson CS, Eberle MA, Kruglyak L, Nickerson DA (2004) Mapping complex disease loci in whole-genome association studies. Nature 429:446-452

30. Chamorro A (2004) Role of inflammation in stroke and atherothrombosis. Cerebrovasc Dis 17:1-5

31. Chowanadisai W, Lönnerdal B, Kelleher SL (2006) Identification of a mutation in SLC30A2 (ZnT-2) in women with low milk zinc concentration that results in transient neonatal zinc deficiency. J Biol Chem 281:39699-39707

32. Christiansen L, Bathum L, Andersen-Ranberg K, Jeune B, Christensen K (2004) Modest implication of interleukin-6 promoter polymorphisms in longevity. Mech Ageing Dev 125:391395

33. Cipriano C, Caruso C, Lio D, Giacconi R, Malavolta M, Muti E, Gasparini N, Franceschi C, Mocchegiani E (2005) The -308G/A polymorphism of TNF-alpha influences immunological parameters in old subjects affected by infectious diseases. Int $\mathbf{J}$ Immunogenet 32:13-18

34. Cipriano C, Malavolta M, Costarelli L, Giacconi R, Muti E, Gasparini N, Cardelli M, Monti D, Mariani E, Mocchegiani E (2006) Polymorphisms in MT1a gene coding region are associated with longevity in Italian Central female population. Biogerontology 7:357-365

35. Cousins RJ (1998) A role of zinc in the regulation of gene expression. Proc Nutr Soc 57:307-311

36. Cousins RJ, Liuzzi JP, Lichten LA (2006) Mammalian zinc transport, trafficking, and signals. J Biol Chem 281:2408524089

37. Dandona P, Aljada A, Bandyopadhyay A (2004) Inflammation, the link between insulin resistance, obesity and diabetes. Trends Immunol 25:4-7

38. Darnton-Hill I, Margetts B, Deckelbaum R (2004) Public health nutrition and genetics: implications for nutrition policy and promotion. Proc Nutr Soc 63:173-185

39. De Benedictis G, Carotenuto L, Carrieri G, De Luca M, Falcone E, Rose G, Cavalcanti S, Corsonello F, Feraco E, Baggio G, Bertolini S, Mari D, Mattace R, Yashin AI, Bonafe M, Franceschi C (1998) Gene/longevity association studies at four autosomal loci (REN, THO, PARP, SOD2). Eur J Hum Genet 6:534-541

40. Devirgiliis C, Zalewski PD, Perozzi G, Murgia C (2007) Zinc fluxes and zinc transporter genes in chronic diseases. Mutat Res 622:84-93

41. Dreosti IE (2001) Zinc and the gene. Mutat Res 475:161-167
42. Ershler WB (1993) Interleukin-6: a cytokine for gerontologists. J Am Geriatr Soc 41:176-181

43. Ershler WB, Sun WH, Binkley N, Gravenstein S, Volk MJ, Kamoske G, Klopp RG, Roecker EB, Daynes RA, Weindruch R (1993) Interleukin-6 and aging: blood levels and mononuclear cell production increase with advancing age and in vitro production is modifiable by dietary restriction. Lymphokine Cytokine Res 12:225-230

44. Ershler WB, Keller ET (2000) Age-associated increased interleukin-6 gene expression, late-life diseases, and frailty. Annu Rev Med 51:245-270

45. Fagiolo U, Cossarizza A, Scala E, Fanales-Belasio E, Ortolani C, Cozzi E, Monti D, Franceschi C, Paganelli R (1993) Increased cytokine production in mononuclear cells of healthy elderly people. Eur J Immunol 23:2375-2378

46. Feder JN, Gnirke A, Thomas W, Tsuchihashi Z, Ruddy DA, Basava A, Dormishian F, Domingo R Jr, Ellis MC, Fullan A, Hinton LM, Jones NL, Kimmel BE, Kronmal GS, Lauer P, Lee VK, Loeb DB, Mapa FA, McClelland E, Meyer NC, Mintier GA, Moeller N, Moore T, Morikang E, Prass CE, Quintana L, Starnes SM, Schatzman RC, Brunke KJ, Drayna DT, Risch NJ, Bacon BR, Wolff RK (1996) A novel MHC class I-like gene is mutated in patients with hereditary haemochromatosis. Nat Genet 13:399-408

47. Ferrucci L, Harris TB, Guralnik JM, Tracy RP, Corti MC, Cohen HJ, Penninx B, Pahor M, Wallace R, Havlik RJ (1999) Serum IL-6 level and the development of disability in older persons. J Am Geriatr Soc 47:639-646

48. Fishman D, Faulds G, Jeffery R, Mohamed-Ali V, Yudkin JS, Humphries S, Woo P (1998) The effect of novel polymorphisms in the interleukin-6 (IL-6) gene on IL-6 transcription and plasma IL-6 levels, and an association with systemic-onset juvenile chronic arthritis. J Clin Invest 102:1369-1376

49. Fonager J, Beedholm R, Clark BF, Rattan SI (2002) Mild stressinduced stimulation of heat-shock protein synthesis and improved functional ability of human fibroblasts undergoing aging in vitro. Exp Gerontol 37:1223-1228

50. Food and Nutrition Board and Institute of Medicine (2000) Dietary references intake for vitamin A, vitamin K, arsenic, boron, chromium, copper, iodine, iron, manganese, molybdenum, nickel, silicon, vanadium and zinc. National Academy Press, Washington, DC

51. Franceschi C, Bonafe M (2003) Centenarians as a model for healthy aging. Biochem Soc Trans 31:457-461

52. Franceschi C, Bonafe M, Valensin S, Olivieri F, De Luca M, Ottaviani E, De Benedictis G (2000) Inflammaging. An evolutionary perspective on immunosenescence. Ann N Y Acad Sci 908:244-254

53. Franceschi C, Olivieri F, Marchegiani F, Cardelli M, Cavallone L, Capri M, Salvioli S, Valensin S, De Benedictis G, Di Iorio A, Caruso C, Paolisso G, Monti D (2005) Genes involved in immune response/inflammation, IGF1/insulin pathway and response to oxidative stress play a major role in the genetics of human longevity: the lesson of centenarians. Mech Ageing Dev 126:351-361

54. Franceschi C, Capri M, Monti D, Giunta S, Olivieri F, Sevini F, Panourgia MP, Invidia L, Celani L, Scurti M, Cevenini E, Castellani GC, Salvioli S (2007) Inflammaging and antiinflammaging: a systemic perspective on aging and longevity emerged from studies in humans. Mech Ageing Dev 128:92-105

55. Fulop T Jr, Larbi A, Dupuis G, Pawelec G (2003) Ageing, autoimmunity and arthritis: perturbations of TCR signal transduction pathways with ageing - a biochemical paradigm for the ageing immune system. Arthritis Res Ther 5:290-302

56. Giacconi R, Cipriano C, Albanese F, Boccoli G, Saba V, Olivieri F, Franceschi C, Mocchegiani E (2004) The-174G/C 
polymorphism of IL-6 is useful to screen old subjects at risk for atherosclerosis or to reach successful ageing. Exp Gerontol 39:621-628

57. Giacconi R, Cipriano C, Muti E, Costarelli L, Cardelli C, Saba V, Gasparini N, Malavolta M, Mocchegiani E (2005) Novel 209A/G MT2A polymorphism in old patients with type 2 diabetes and atherosclerosis: relationship with inflammation (IL-6) and zinc. Biogerontology 6:407-413

58. Giacconi R, Cipriano C, Muti E, Costarelli L, Malavolta M, Caruso C, Lio D, Mocchegiani E (2006) Involvement of -308 TNF-alpha and 1267 Hsp70-2 polymorphisms and zinc status in the susceptibility of coronary artery disease (CAD) in old patients. Biogerontology 7:347-356

59. Giacconi R, Muti E, Malavolta M, Cardelli M, Pierpaoli S, Cipriano C, Costarelli L, Tesei S, Saba V, Mocchegiani E (2008) A novel zip2 gln/arg/leu codon 2 polymorphism is associated with carotid artery disease in aging. Rejuvenation Res 11:297-300

60. Goyette P, Sumner JS, Milos R, Duncan AM, Rosenblatt DS, Matthews RG, Rozen R (1994) Human methylenetetrahydrofolate reductase: isolation of cDNA mapping and mutation identification. Nat Genet 7:551

61. Grallert H, Sedlmeier EM, Huth C, Kolz M, Heid IM, Meisinger C, Herder C, Strassburger K, Gehringer A, Haak M, Giani G, Kronenberg F, Wichmann HE, Adamski J, Paulweber B, Illig T, Rathmann W (2007) APOA5 variants and metabolic syndrome in Caucasians. J Lipid Res 48:2614-2621

62. Guenther BD, Sheppard CA, Tran P, Rozen R, Matthews RG, Ludwig ML (1999) The structure and properties of methylenetetrahydrofolate reductase from Escherichia coli suggest how folate ameliorates human hyperhomocysteinemia. Nat Struct Biol 6:359-365

63. Haase H, Rink L (2007) Signal transduction in monocytes: the role of zinc ions. Biometals 20:579-585

64. Hajeer AH, Hutchinson IV (2001) Influence of TNFalpha gene polymorphisms on TNFalpha production and disease. Hum Immunol 62:1191-1199

65. Hambidge M (2003) Biomarkers of trace mineral intake and status. J Nutr 133(Suppl 3):948S-955S

66. Hao Q, Maret W (2006) Aldehydes release zinc from proteins. A pathway from oxidative stress/lipid peroxidation to cellular functions of zinc. FEBS J 273:4300-4310

67. Hatayama T, Asai Y, Wakatsuki T, Kitamura T, Imahara H (1993) Regulation of hsp70 synthesis induced by cupric sulfate and zinc sulfate in thermotolerant HeLa cells. J Biochem 114:592-597

68. Heinrich PC, Behrmann I, Haan S, Hermanns HM, MullerNewen G, Schaper F (2003) Principles of interleukin (IL)-6-type cytokine signalling and its regulation. Biochem J 374:1-20

69. Helfand SL, Rogina B (2003) From genes to aging in Drosophila. Adv Genet 49:67-109

70. Hightower LE (1991) Heat shock, stress proteins, chaperones, and proteotoxicity. Cell 66:191-197

71. Holmes CL, Russell JA, Walley KR (2003) Genetic polymorphisms in sepsis and septic shock: role in prognosis and potential for therapy. Chest 124:1103-1115

72. Huang H, Patel DD, Manton KG (2005) The immune system in aging: roles of cytokines, T cells and NK cells. Front Biosci 10:192-215

73. Janeway C, Travers P, Walport M, Capra A (1999) The immune system in health and disease. Garland Publishers, New York

74. Jang Y, Kim JY, Kim OY, Lee JE, Cho H, Ordovas JM, Lee JH (2004) The -1131T-\&gt;C polymorphism in the apolipoprotein A5 gene is associated with postprandial hypertriacylglycerolemia; elevated small, dense LDL concentrations; and oxidative stress in nonobese Korean men. Am J Clin Nutr 80:832-840
75. Jarvik GP, Rozek LS, Brophy VH, Hatsukami TS, Richter RJ, Schellenberg GD, Furlong CE (2000) Paraoxonase (PON1) phenotype is a better predictor of vascular disease than is PON1(192) or PON1(55) genotype. Arterioscler Thromb Vasc Biol 20:2441-2447

76. Jarvik GP, Hatsukami TS, Carlson C, Richter RJ, Jampsa R, Brophy VH, Margolin S, Rieder M, Nickerson D, Schellenberg GD, Heagerty PJ, Furlong CE (2003) Paraoxonase activity, but not haplotype utilizing the linkage disequilibrium structure, predicts vascular disease. Arterioscler Thromb Vasc Biol 23:1465-1471

77. Jazwinska EC, Cullen LM, Busfield F et al (1996) Haemochromatosis and HLA-H. Nat Genet 14:249-251

78. Jilka RL, Hangoc G, Girasole G, Passeri G, Williams DC, Abrams JS, Boyce B, Broxmeyer H, Manolagas SC (1992) Increased osteoclast development after estrogen loss: mediation by interleukin-6. Science 257:88-91

79. Jin X, Xiao C, Tanguay RM, Yang L, Wang F, Chen M, Fu X, Wang R, Deng J, Deng Z, Zheng Y, Wei Q, Wu T (2004) Correlation of lymphocyte heat shock protein 70 levels with neurologic deficits in elderly patients with cerebral infarction. Am J Med 117:406-411

80. Jordanides N, Eskdale J, Stuart R, Gallagher G (2000) Allele associations reveal four prominent haplotypes at the human interleukin-6 (IL-6) locus. Genes Immun 1:451-455

81. Kado S, Nagata N (1999) Circulating intercellular adhesion molecule-1, vascular cell adhesion molecule-1, and E-selectin in patients with type 2 diabetes mellitus. Diabetes Res Clin Pract 46:143-148

82. Kirkwood TB (2002) Evolution of ageing. Mech Ageing Dev 123:737-745

83. Knoops KT, de Groot LC, Kromhout D, Perrin AE, MoreirasVarela O, Menotti A, van Staveren WA (2004) Mediterranean diet, lifestyle factors, and 10-year mortality in elderly European men and women: the HALE project. JAMA 292:14331439

84. Kojima T, Kamei H, Aizu T, Arai Y, Takayama M, Nakazawa S, Ebihara Y, Inagaki H, Masui Y, Gondo Y, Sakaki Y, Hirose N (2004) Association analysis between longevity in the Japanese population and polymorphic variants of genes involved in insulin and insulin-like growth factor 1 signaling pathways. Exp Gerontol 39:1595-1598

85. Krabbe KS, Pedersen M, Bruunsgaard H (2004) Inflammatory mediators in the elderly. Exp Gerontol 39:687-699

86. Kuningas M, Mooijaart SP, van Heemst D, Zwaan BJ, Slagboom PE, Westendorp RG (2008) Genes encoding longevity: from model organisms to humans. Aging Cell 7:270-280

87. Lee JS, Lee JJ, Seo JS (2005) HSP70 deficiency results in activation of c-Jun N-terminal Kinase, extracellular signal-regulated kinase, and caspase-3 in hyperosmolarity-induced apoptosis. J Biol Chem 280:6634-6641

88. Lio D, Candore G, Colombo A, Colonna Romano G, Gervasi F, Marino V, Scola L, Caruso C (2001) A genetically determined high setting of TNF-alpha influences immunologic parameters of HLA-B8, DR3 positive subjects: implications for autoimmunity. Hum Immunol 62:705-713

89. Lio D, Scola L, Crivello A, Colonna-Romano G, Candore G, Bonafe M, Cavallone L, Marchegiani F, Olivieri F, Franceschi C, Caruso C (2003) Inflammation, genetics, and longevity: further studies on the protective effects in men of IL-10-1082 promoter SNP and its interaction with TNF-alpha-308 promoter SNP. J Med Genet 40:296-299

90. Lyons TJ, Gasch AP, Gaither LA, Botstein D, Brown PO, Eide DJ (2000) Genome-wide characterization of the Zap1p zincresponsive regulon in yeast. Proc Natl Acad Sci USA 97:79577962 
91. Ma J, Stampfer MJ, Christensen B, Giovannucci E, Hunter DJ, Chen J, Willett WC, Selhub J, Hennekens CH, Gravel R, Rozen $\mathrm{R}$ (1999) A polymorphism of the methionine synthase gene: association with plasma folate, vitamin B12, homocyst(e)ine, and colorectal cancer risk. Cancer Epidemiol Biomarkers Prev 8:825-829

92. Malavolta M, Costarelli L, Giacconi R, Muti E, Bernardini G, Tesei S, Cipriano C, Mocchegiani E (2006) Single and threecolor flow cytometry assay for intracellular zinc ion availability in human lymphocytes with Zinpyr-1 and double immunofluorescence: relationship with metallothioneins. Cytometry A 69:1043-1053

93. Maret W, Jacob C, Vallee BL, Fischer EH (1999) Inhibitory sites in enzymes: zinc removal and reactivation by thionein. Proc Natl Acad Sci USA 96:1936-1940

94. Marini M, Lapalombella R, Canaider S, Farina A, Monti D, De Vescovi V, Morellini M, Bellizzi D, Dato S, De Benedictis G, Passarino G, Moresi R, Tesei S, Franceschi C (2004) Heat shock response by EBV-immortalized B-lymphocytes from centenarians and control subjects: a model to study the relevance of stress response in longevity. Exp Gerontol 39:83-90

95. Mariani E, Neri S, Cattini L, Mocchegiani E, Malavolta M, Dedoussis GV, Kanoni S, Rink L, Jajte J, Facchini A (2008) Effect of zinc supplementation on plasma IL-6 and MCP-1 production and NK cell function in healthy elderly: interactive influence of +647 MT1a and -174 IL-6 polymorphic alleles. Exp Gerontol 43:462-471

96. Mattson MP (2008) Dietary factors, hormesis and health. Ageing Res Rev 7:43-48

97. Maverakis E, Fung MA, Lynch PJ, Draznin M, Michael DJ, Ruben B, Fazel N (2007) Acrodermatitis enteropathica and an overview of zinc metabolism. J Am Acad Dermatol 56:116124

98. Mazzatti DJ, Malavolta M, White AJ, Costarelli L, Giacconi R, Muti E, Cipriano C, Powell JR, Mocchegiani E (2008) Effects of interleukin-6-174C/G and metallothionein $1 \mathrm{~A}+647 \mathrm{~A} / \mathrm{C}$ singlenucleotide polymorphisms on zinc-regulated gene expression in ageing. Exp Gerontol 43:423-432

99. Milner CM, Campbell RD (1990) Structure and expression of the three MHC-linked HSP70 genes. Immunogenetics 32:242251

100. Mira JP, Cariou A, Grall F, Delclaux C, Losser MR, Heshmati F, Cheval C, Monchi M, Teboul JL, Riche F, Leleu G, Arbibe L, Mignon A, Delpech M, Dhainaut JF (1999) Association of TNF2, a TNF-alpha promoter polymorphism, with septic shock susceptibility and mortality: a multicenter study. JAMA 282:561-568

101. Mitchell BD, Hsueh WC, King TM, Pollin TI, Sorkin J, Agarwala R, Schaffer AA, Shuldiner AR (2001) Heritability of life span in the Old Order Amish. Am J Med Genet 102:346-352

102. Mitrou PN, Kipnis V, Thiébaut AC, Reedy J, Subar AF, Wirfält E, Flood A, Mouw T, Hollenbeck AR, Leitzmann MF, Schatzkin A (2007) Mediterranean dietary pattern and prediction of allcause mortality in a US population: results from the NIH-AARP Diet and Health Study. Arch Intern Med 167:2461-2468

103. Mocchegiani E, Muzzioli M, Cipriano C, Giacconi R (1998) Zinc, T-cell pathways, aging: role of metallothioneins. Mech Ageing Dev 106:183-204

104. Mocchegiani E, Muzzioli M, Giacconi R (2000) Zinc and immunoresistance to infection in aging: new biological tools. Trends Pharmacol Sci 21:205-208

105. Mocchegiani E, Giacconi R, Cipriano C, Muzzioli M, Gasparini N, Moresi R, Stecconi R, Suzuki H, Cavalieri E, Mariani E (2002) MtmRNA gene expression, via IL-6 and glucocorticoids, as potential genetic marker of immunosenescence: lessons from very old mice and humans. Exp Gerontol 37:349-357
106. Mocchegiani E, Giacconi R, Muti E, Rogo C, Bracci M, Muzzioli M, Cipriano C, Malavolta M (2004) Zinc, immune plasticity, aging, and successful aging: role of metallothionein. Ann N Y Acad Sci 1019:127-134

107. Mocchegiani E, Costarelli L, Giacconi R, Cipriano C, Muti E, Tesei S, Malavolta M (2006) Nutrient-gene interaction in ageing and successful ageing. A single nutrient (zinc) and some target genes related to inflammatory/immune response. Mech Ageing Dev 127:517-525

108. Mocchegiani E, Giacconi R, Costarelli L, Muti E, Cipriano C, Tesei S, Pierpaoli S, Giuli C, Papa R, Marcellini F, Gasparini N, Pierandrei R, Piacenza F, Mariani E, Monti D, Dedoussis G, Kanoni S, Herbein G, Fulop T, Rink L, Jajte J, Malavolta M (2008) Zinc deficiency and IL-6-174G/C polymorphism in old people from different European countries: effect of zinc supplementation. ZINCAGE study. Exp Gerontol 43:433-444

109. Morimoto RI (1993) Cells in stress: transcriptional activation of heat shock genes. Science 259:1409-1410

110. Moroni F, Di Paolo ML, Rigo A, Cipriano C, Giacconi R, Recchioni R, Marcheselli F, Malavolta M, Mocchegiani E (2005) Interrelationship among neutrophil efficiency, inflammation, antioxidant activity and zinc pool in very old age. Biogerontology 6:271-281

111. Mysliwska J, Bryl E, Foerster J, Mysliwski A (1998) Increase of interleukin 6 and decrease of interleukin 2 production during the ageing process are influenced by the health status. Mech Ageing Dev 100:313-328

112. Nadel S, Newport MJ, Booy R, Levin M (1996) Variation in the tumor necrosis factor-alpha gene promoter region may be associated with death from meningococcal disease. J Infect Dis 174:878-880

113. Newton-Cheh C, Hirschhorn JN (2005) Genetic association studies of complex traits: design and analysis issues. Mutat Res 573:54-69

114. Olivieri F, Bonafe M, Cavallone L, Giovanetti S, Marchigiani F, Cardelli M, Mugianesi E, Giampieri C, Moresi R, Stecconi R, Lisa R, Franceschi C (2002) The $-174 \mathrm{C} / \mathrm{G}$ locus affects in vitro/ in vivo IL-6 production during aging. Exp Gerontol 37:309-314

115. Olivieri F, Bonafè M, Giovagnetti S, Stecconi R, Cardelli M, Cavallone L, Spazzafumo L, Marchegiani F, Carrieri G, Mugianesi E, Giampieri C, Centurelli M, Moresi R, Tesei S, Lisa R, Viticchi C, Falsetti L, Salvioli S, Franceschi C (2003) In vitro IL-6 production by EBV-immortalized B lymphocytes from young and elderly people genotyped for $-174 \mathrm{C} / \mathrm{G}$ polymorphism in IL-6 gene: a model to study the genetic basis of inflamm-aging. Mech Ageing Dev 124:549-553

116. Osiri M, McNicholl J, Moreland LW, Bridges SL Jr (1999) A novel single nucleotide polymorphism and five probable haplotypes in the $5^{\prime}$ flanking region of the IL- 6 gene in AfricanAmericans. Genes Immun 1:166-167

117. Ota N, Nakajima T, Nakazawa I, Suzuki T, Hosoi T, Orimo H, Inoue S, Shirai Y, Emi M (2001) A nucleotide variant in the promoter region of the interleukin-6 gene associated with decreased bone mineral density. J Hum Genet 46:267-272

118. Pahlavani MA, Harris MD, Moore SA, Richardson A (1996) Expression of heat shock protein 70 in rat spleen lymphocytes is affected by age but not by food restriction. J Nutr 126:20692075

119. Palmiter RD (1998) The elusive function of metallothioneins. Proc Natl Acad Sci USA 95:8428-8430

120. Paolisso G, Barbieri M (2001) Response to "Serum insulin-like growth factor-1 (IGF-1) in centenarians: implications of IGF-1 as a turnover protein". J Gerontol A Biol Sci Med Sci 56:M662M663

121. Pawelec G, Barnett Y, Forsey R, Frasca D, Globerson A, McLeod J, Caruso C, Franceschi C, Fulop T, Gupta S, Mariani 
E, Mocchegiani E, Solana R (2002) T cells and aging. Front Biosci 7:1056-1183

122. Piano A, Valbonesi P, Fabbri E (2004) Expression of cytoprotective proteins, heat shock protein 70 and metallothioneins, in tissues of Ostrea edulis exposed to heat and heavy metals. Cell Stress Chaperones 9:134-142

123. Prandota J (2005) Important role of proinflammatory cytokines/ other endogenous substances in drug-induced hepatotoxicity: depression of drug metabolism during infections/inflammation states, and genetic polymorphisms of drug-metabolizing enzymes/cytokines may markedly contribute to this pathology. Am J Ther 12:254-261

124. Prasad AS (2000) Effects of zinc deficiency on Th1 and Th2 cytokine shifts. J Infect Dis 182(Suppl 1):S62-S68

125. Prasad AS (2008) Zinc in human health: effect of zinc on immune cells. Mol Med 14:353-357

126. Prasad AS, Bao B, Beck FW, Kucuk O, Sarkar FH (2004) Antioxidant effect of zinc in humans. Free Radic Biol Med 37:182-1190

127. Putics A, Vödrös D, Malavolta M, Mocchegiani E, Csermely P, Soti C (2008) Zinc supplementation boosts the stress response in the elderly: Hsp70 status is linked to zinc availability in peripheral lymphocytes. Exp Gerontol 43:452-461

128. Rattan SI (2004) Aging intervention, prevention, and therapy through hormesis. J Gerontol A Biol Sci Med Sci 59:705709

129. Rea IM, Ross OA, Armstrong M, McNerlan S, Alexander DH, Curran MD, Middleton D (2003) Interleukin-6-gene C/G 174 polymorphism in nonagenarian and octogenarian subjects in the BELFAST study. Reciprocal effects on IL-6, soluble IL-6 receptor and for IL-10 in serum and monocyte supernatants. Mech Ageing Dev 124:555-561

130. Rea IM, McKeown PP, McMaster D, Young IS, Patterson C, Savage MJ, Belton C, Marchegiani F, Olivieri F, Bonafe M, Franceschi C (2004) Paraoxonase polymorphisms PON1 192 and 55 and longevity in Italian centenarians and Irish nonagenarians. A pooled analysis. Exp Gerontol 39:629-635

131. Ross CM (1999) Re: prospective study of adult onset diabetes mellitus (Type 2) and risk of colorectal cancer in women. J Natl Cancer Inst 91:1334

132. Rothe J, Gehr G, Loetscher H, Lesslauer W (1992) Tumor necrosis factor receptors-structure and function. Immunol Res 11:81-90

133. Sehgal PB, Zilberstein A, Ruggieri RM, May LT, FergusonSmith A, Slate DL, Revel M, Ruddle FH (1986) Human chromosome 7 carries the beta 2 interferon gene. Proc Natl Acad Sci USA 83:5219-5222

134. Sekler I, Sensi SL, Hershfinkel M, Silverman WF (2007) Mechanism and regulation of cellular zinc transport. Mol Med 13:337-343

135. Semenza JC, Rubin CH, Falter KH, Selanikio JD, Flanders WD, Howe HL, Wilhelm JLN (1996) Heat-related deaths during the July 1995 heat wave in Chicago. N Engl J Med 335:84-90

136. Sladek R, Rocheleau G, Rung J, Dina C, Shen L, Serre D, Boutin P, Vincent D, Belisle A, Hadjadj S, Balkau B, Heude B, Charpentier G, Hudson TJ, Montpetit A, Pshezhetsky AV, Prentki M, Posner BI, Balding DJ, Meyre D, Polychronakos C, Froguel P (2007) A genome-wide association study identifies novel risk loci for type 2 diabetes. Nature 445:881-885

137. Soti C, Csermely P (2000) Molecular chaperones and the aging process. Biogerontology 1:225-233

138. Spahl DU, Berendji-Grun D, Suschek CV, Kolb-Bachofen V, Kroncke KD (2003) Regulation of zinc homeostasis by inducible NO synthase-derived NO: nuclear metallothionein translocation and intranuclear $\mathrm{Zn}^{2+}$ release. Proc Natl Acad Sci USA 100:13952-13957
139. Stephens JC, Schneider JA, Tanguay DA, Choi J, Acharya T, Stanley SE, Jiang R, Messer CJ, Chew A, Han JH, Duan J, Carr JL, Lee MS, Koshy B, Kumar AM, Zhang G, Newell WR, Windemuth A, Xu C, Kalbfleisch TS, Shaner SL, Arnold K, Schulz V, Drysdale CM, Nandabalan K, Judson RS, Ruano G, Vovis GF (2001) Haplotype variation and linkage disequilibrium in 313 human genes. Science 293:489-493

140. Stover PJ (2006) Influence of human genetic variation on nutritional requirements. Am J Clin Nutr 83:436S-442S

141. Stuber F, Petersen M, Bokelmann F, Schade UA (1996) Genomic polymorphism within the tumor necrosis factor locus influences plasma tumor necrosis factor-alpha concentrations and outcome of patients with severe sepsis. Crit Care Med 24:381-384

142. Swallow DM (2003) Genetics of lactase persistence and lactose intolerance. Annu Rev Genet 37:197-219

143. Tang GJ, Huang SL, Yien HW, Chen WS, Chi CW, Wu CW, Lui WY, Chiu JH, Lee TY (2000) Tumor necrosis factor gene polymorphism and septic shock in surgical infection. Crit Care Med 28:2733-2736

144. Terry DF, Wyszynski DF, Nolan VG, Atzmon G, Schoenhofen EA, Pennington JY, Andersen SL, Wilcox MA, Farrer LA, Barzilai N, Baldwin CT, Asea A (2006) Serum heat shock protein 70 level as a biomarker of exceptional longevity. Mech Ageing Dev 127:862-868

145. Terry CF, Loukaci V, Green FR (2000) Cooperative influence of genetic polymorphisms on interleukin 6 transcriptional regulation. J Biol Chem 275:18138-18144

146. Tilg H, Trehu E, Atkins MB, Dinarello CA, Mier JW (1994) Interleukin-6 (IL-6) as an anti-inflammatory cytokine: induction of circulating IL-1 receptor antagonist and soluble tumour necrosis factor receptor p55. Blood 83:113-118

147. Tracey KJ (2002) The inflammatory reflex. Nature 420:853-859

148. Vallee BL (1995) The function of metallothionein. Neurochem Int 27:23-33

149. Vanden Berghe W, Vermeulen L, De Wilde G, De Bosscher K, Boone E, Haegeman G (2000) Signal transduction by tumor necrosis factor and gene regulation of the inflammatory cytokine interleukin-6. Biochem Pharmacol 60:1185-1195

150. Vasák ML (2005) Advances in metallothionein structure and functions. J Trace Elem Med Biol 19:13-17

151. Vassalli P (1992) The pathophysiology of tumor necrosis factors. Annu Rev Immunol 10:411-452

152. Wang XY, Hurme M, Jylha M, Hervonen A (2001) Lack of association between human longevity and polymorphisms of IL1 cluster, IL-6, IL-10 and TNF-alpha genes in Finnish nonagenarians. Mech Ageing Dev 123:29-38

153. Webb GC, Chaplin DD (1990) Genetic variability at the human tumour necrosis factor loci. Immunology 145:1278-1285

154. Welch WJ (1992) Mammalian stress response: cell physiology, structure/function of stress proteins, and implications for medicine and disease. Physiol Rev 72:1063-1081

155. West AK, Stallings R, Hildebrand CE, Chiu R, Karin M, Richards RI (1990) Human metallothionein genes: structure of the functional locus at 16q13. Genomics 8:513-518

156. Williams GC (1957) Pleiotropy, natural selection and the evolution of senescence. Evolution 11:398-411

157. Yasukawa K, Hirano T, Watanabe Y, Muratani K, Matsuda T, Nakai S, Kishimoto T (1987) Structure and expression of human B cell stimulatory factor-2 (BSF-2/IL-6) gene. EMBO J 6:29392945

158. Yenari MA (2002) Heat shock proteins and neuroprotection. Adv Exp Med Biol 513:281-299

159. Yokoyama K, Fukumoto K, Murakami T, Harada S, Hosono R, Wadhwa R, Mitsui Y, Ohkuma S (2002) Extended longevity of Caenorhabditis elegans by knocking in extra copies of hsp70F, 
a homolog of mot-2 (mortalin)/mthsp70/Grp75. FEBS Lett 516:53-57

160. Young DG, Skibinski G, Mason JI, James K (1999) The influence of age and gender on serum dehydroepiandrosterone sulphate (DHEA-S), IL-6, IL-6 soluble receptor (IL-6 sR) and transforming growth factor beta 1 (TGF-beta1) levels in normal healthy blood donors. Clin Exp Immunol 117:476-481
161. Zilberstein A, Ruggieri R, Korn JH, Revel M (1986) Structure and expression of cDNA and genes for human interferon-beta-2, a distinct species inducible by growth-stimulatory cytokines. EMBO J 5:2529-2537

162. Zondervan KT, Cardon LR (2004) The complex interplay among factors that influence allelic association. Nat Rev Genet 5:89-100 